\title{
Experiencing Practical Knowledge
}

Emerging Convergences of Pragmatism and Sociological Practice Theory

Tanja Bogusz

\section{(2) OpenEdition}

Electronic version

URL: http://journals.openedition.org/ejpap/765

DOI: 10.4000/ejpap.765

ISSN: 2036-4091

\section{Publisher}

Associazione Pragma

Electronic reference

Tanja Bogusz, «Experiencing Practical Knowledge », European Journal of Pragmatism and American Philosophy [Online], IV - 1 | 2012, Online since 23 July 2012, connection on 20 April 2019. URL : http:// journals.openedition.org/ejpap/765 ; DOI : 10.4000/ejpap.765

This text was automatically generated on 20 April 2019.

\section{(i) (9)}

Author retains copyright and grants the European Journal of Pragmatism and American Philosophy right of first publication with the work simultaneously licensed under a Creative Commons AttributionNonCommercial-NoDerivatives 4.0 International License. 


\section{Experiencing Practical Knowledge}

Emerging Convergences of Pragmatism and Sociological Practice Theory

Tanja Bogusz

\section{Introduction}

"Pragmatism and sociology" observed Émile Durkheim in 1914, share "a sense of life and action. Both are children of the same era" (Durkheim 1983: 1). This assumption has gained ground in current social science and humanities discourse, in particular in France and Germany, a development I shall examine below. Following the skepticism of postmodernism, both practice theory and pragmatism are undergoing a renaissance that can be seen not least in the so-called epistemological turns of the past decade. Thus the "practice turn" of the 1990s was followed by the "pragmatic turn" of the beginning of the 21st century internationally in social and cultural sciences as well as in philosophy. Despite the obvious convergences of both traditions of thought, there has not yet been a systematic analysis of their epistemological convergences. ${ }^{1}$ This essay addresses this desideratum through a comparative analysis of the sociologists Émile Durkheim and Pierre Bourdieu and the philosophers William James and John Dewey. Without a doubt, these four protagonists are different in many respects. Durkheim rejected the vitalist principles that characterized James' pragmatism and radical empiricism, and Bourdieu did not embrace Dewey's political optimism about social and cognitive spaces of opportunity that could potentially support social change towards a more democratic and humane society. It seems it is exactly these distinctions that differentiated sociology from pragmatism from the very beginning and that, at least in francophone countries, long hindered pragmatism from gaining the recognition and attention in Europe that it deserved. The situation in Germany was not much better until Hans Joas has introduced American pragmatism into German sociological theory. At the same time, no connections were made between pragmatism and the epistemological foundations of Pierre Bourdieu's practice theory, which the late Frankfurter School saw as utilitarian cultural sociology 
(Honneth 1984, Joas \& Knöbl 2004); practice theory's call for the creation of theory based on experience and empirical reflection was applied anything but stringently.

The French neo-pragmatic movement under the label of the "sociologie pragmatique de la critique" was constituted in the early 1990's notably by ex-scholars of Bourdieu against his sociology, or, more precisely, against the structuralist heritage in his conception of the habitus. On the other hand, and without making it explicit, it reinforced Bourdieu's practical epistemology through an ethnomethodological and actor-centered perspective, that had obviously inspired Bourdieu's own practice as a researcher, but was widely neglected in his theoretical architecture. Moreover and curiously enough, the French pragmatic movement was itself not originated by a reception of the American classics. In a way, these inconsistencies contributed to the general idea that pragmatism and practice theory have not much in common. However in the meantime, over ten years after Bourdieu's death, today it is again possible to take up the idea of Bourdieu's practice theory free of the former Parisian trench fighting (Boltanski 2008, 2009; De Fornel \& Ogien 2011) and at the same time systematically re-read James' and Dewey's writings (De Fornel \& Lemieux 2007; Karsenti 2007) and conceptualize them anew for the sociological theory of knowledge (Thévenot 2011). This is the impulse I have followed.

Practice, in James' and Dewey's pragmatism, as well as in Durkheim's and Bourdieu's sociology, signifies first of all an anthropological category. Its material, physical and cognitive complexity is that it refers equally to contradictory states ever-present in homo duplex: difference and repetition, creation and reproduction, action and reflection, volatility and stability. This definition of practice contrasts - particularly explicitly in Dewey and Bourdieu's writings - on an epistemological level with a reason-centered and universalistic concept of humanity that was again radically questioned by the postmodern ideas of the 1990s. At the same time, this concept nevertheless created an awareness of the considerable power of institutions and structures both to reinforce social inequality and to question its internalization and modification through practice. "Practice" is at the same time the critical counterpart to "theory," provided that the latter is not hypostatized as the origin of knowledge. The creation of a dichotomy between theory and practice is already the starting point of all four authors' critiques of consciousness considering the philosophy and humanities of their respective times. In this sense, the term practice is very close to concepts of "experience" (in Bourdieu "disposition"), "knowledge" and "emergence" - an idea that already informed Durkheim's thought and also allows for a connection between pragmatism and practice theory as I shall suggest below.

4 My assumption is that an interpretation - based on emergence theory - of the categories central to both these schools; experience/disposition, knowledge and practice shall make an explicit combination of pragmatism and a sociological theory of practice possible that has not yet been attempted and that takes into account both socio-structural limits and contingent and optional spaces of possibility. In my use of the practice-oriented term “emergence," I use Wolfgang Krohn and Günther Küppers' definition: the appearance of a new quality characterized by a specific "self-organized dynamic of process" (Krohn \& Küppers 1992: 7-8) ${ }^{2}$ considering the fact, that, as Neil Gross points out, "pragmatists suggest that means and ends are not always given prior to action [...], but are instead often emergent from action. [...] This is especially the case in situations of ambiguity, which pragmatism is uniquely poised to make sense of' (Gross 2009: 367). This processual dynamic is especially important to the prominence of practice in terms of its ability to 
form reality, its creative force, central to both practice theory and experimental thinking. For James and for Dewey, as well as for Bourdieu, knowledge is a mode of practical action based on the fundamental rejection of an essentialist point of reference divorced from action. They were interested in the dynamics of human action as a practical construction of the social. I therefore take a particularly close look at James' and Durkheim's theories of knowledge and action and the meaning of (collective) "experience" (1). I then compare the terms "experience" and "practice" in the philosophy of John Dewey and Pierre Bourdieu's theory of knowledge and society (2). Finally, I shall make an attempt to explain why conceptualizing these approaches using a theory of emergence is important for a pragmatist theory of practice that is yet to be developed (3).

\section{Modern Critiques of Consciousness in France and the USA: Durkheim's "sociologie de l'action" and James' "Radical Empiricism"}

5 At the start of the twentieth century, Émile Durkheim elevated sociology to a discipline that, not incidentally, in France oscillated between scientific positivism and metaphysical philosophy. This new French discipline could only gain as philosophy and the natural sciences vied for interpretative supremacy. Durkheim's anti-fundamentalist criticism of teleological metaphysics on the one hand and empirical determinism on the other hand sparked passionate debates at the turn of the century on how best to grasp the societal challenges of the modern era. This is the point at which Durkheim's empirical social science connects with American pragmatism and which accentuates his sociological method. Durkheim's claim to a completely new social science, genetically and empirically, has a worthy opponent in William James' pragmatism and radical empiricism.

6 Durkheim's lectures on pragmatism, held in the winter of 1913/14, but first published in 1955 from students' notes, were a reaction to three questions articulated by the pragmatist movement: 1) The meaning of experience for the constitution of social reality, 2) The centrality of action and practice to gaining knowledge and, finally, 3) The search for a method to gauge the relationship between empirical facts and individual and collective consciousness. According to Hans Joas and the French philosopher Bruno Karsenti, the importance of Durkheim's pragmatism lectures as a component of his sociologie de l'action has been underestimated to date. Thus both sociology and pragmatism made an important early contribution to practice theory, most recently discussed in the context of the so-called practice turn (Karsenti 2006: 162-3; Karsenti 2007: 139).

7 The pragmatists' epistemological interest arose from an underlying anthropological assumption; ${ }^{3}$ that humans can be distinguished from animals by their reduced instincts. As a result, they meet crisis situations with neither a universally given nor internalized spectrum of action, but rather must experiment. In his well-known 1878 essay "How to make our ideas clear," C. S. Peirce founded pragmatism as an epistemological semiotics and a means of clarifying the practical significance of terminology. Peirce, James and Dewey were searching for methodological connecting points between natural sciences and philosophical epistemology. The problem with philosophy, as Dewey in particular never tired of saying, is its insistence on metaphysically founded absolute certainty from which it defended its dominance in the humanities in the face of the growing omnipresence of the natural sciences. The philosophy of pragmatism on the other hand, 
was based on the underlying assumption that both quotidian and scientific knowledge is based primarily on experience and practice. Knowledge represents therefore a hypothetical endeavor, while practice has both a creative and an experimental character. For James, John Dewey summarized James' accomplishment in this context as follows: “In brief, James's theory is replacing the traditional concept of absolute truth with experimentalism" (MW 12: 220).

8 The sociologist Durkheim was skeptical about this epistemological optimism. For one thing, he doubted the existence of unfettered possibilities espoused by experimental thinking, he rather believed in constrictive social norms; he also found that the pragmatists ignored the importance of history by their emphasis on the new social spaces of possibility opened up by the modern era, the structural framework of which was equally created and limited by the freedom of the human will (Durkheim 1982: 134-5). James believed these spaces of possibility were based on experiences in the world and of the world in which old truths and new experiences collaborate, a particular focus of his radical empiricism. James' pragmatism sought in the end to ensure the connection of truth and usefulness. While Peirce's "pragmaticism," as he later renamed his philosophy to distinguish it from James', concentrated on applying mathematical logic to philosophical knowledge in order to introduce it to philosophy through an experimental method of abduction - building hypotheses - as a "laboratory habit of mind," James, a psychologist, applied naturalist methods to practice-based cognition. A polemic against both rationalism and (particularly Humean) empiricism, pragmatism aimed also to refer to a basic method of thinking; both a theory of reality and a genetic theory of truth. The pragmatic method should act as an intermediary between different perspectives, highlighting their transformative elements, as James explained in 1907 in "Pragmatism": It is thus an "indication of the ways in which existing realities may be changed. Theories become thus instruments, not answers to enigmas, in which we can rest. We won't lie upon them, we move forward, and, on occasion, make nature over again by their aid" (James 1978: 32). Similar to Durkheim's sociology, pragmatists are in opposition to all essentialist tendencies in the philosophical tradition that divided the empirical from theory. Durkheim's sociology is also instrumental and interventionist; not only in terms of its methodological approach but also in terms of its practical function - in two senses a sociologie de l'action. But how do James' philosophy and Durkheim's sociology correspond in regard to their respective aims?

\subsection{Experience and Collective Consciousness}

9 The following examination of Durkheim's comments on pragmatism elucidates the way in which Durkheim was able to hone his original sociological arguments by grappling with James. The term "experience" is central to both; as a new critique of consciousness it is one of the most important paradigms in the modern humanities. Bruno Karsenti observes that Durkheim's "opposition to pragmatism [is] [...] just as clear as to Kantianism and empiricism. However it makes the relentlessness and the specificity of Durkheim's thesis clear, which attempts to prevail against the challenges of a theory, which itself acted similarly at its onset, by overcoming both classical theoretical trends by redefining 'experience.' Accordingly one could ask whether [Durkheim's] socio-empiricism is not primarily a sociological version of 'radical empiricism"' (Karsenti 2007: 134). ${ }^{4}$ 
10 Karsenti is referring here to the lectures on pragmatism and to Durkheim's studies on the sociology of religion which for some time have been discussed in France and in the USA as "socio-empiricism" in regards to the impulses they provided for practice theory (Rawls 1996; De Fornel \& Lemieux 2007). Both James and Durkheim phrase their humanist critique of consciousness as a radical empiricist attack on metaphysical ideas of consciousness: "Truth thus means, according to humanism, the relation of less fixed parts of experience (predicates) to other relatively fixed parts (subjects); and we are not required to seek it in a relation of experience as such to anything beyond itself" (James 1975: 212). James' radical empiricism thus refers primarily the attempt to bring together the process of the relation of experiences with the demands of any given reality; or to connect rational and empirical thought. ${ }^{5}$ In his famous 1904 essay "Does consciousness exist?" James even goes so far as to take complete leave of the term "consciousness" in favor of its "pragmatic equivalent in realities of experience." However, since this thought appears absurd to him he adds:

that I mean only to deny that the word stands for an entity, but to insist most emphatically that it does stand for a function. [...] [T]here is a function in experience which thoughts perform, and for the performance of which this quality of being is invoked. That function is knowing. (James 1922: 3-4)

11 Radical empiricism as a critique of consciousness seeks to debunk the underlying ontological assumption of an absolute origin of consciousness, as David Lapoujade emphasizes:

To free the self from the assignation to an origin at the same time frees human action from an organizational plan hidden in nature, with the mind subjugated to its effects. There is no plan other than the organizational plan of experience. (Lapoujade 2008: 185)

Seen this way, both radical empiricism and Durkheim aspire to connect to the Lebenswelt (life-world), however Durkheim doubts that it is possible to capture consciousness within social reality using James' at the same time abstract and subject-oriented terminology of "pure experience" or the "stream of experience." He criticizes James' vitalist approach, a criticism he also aims at his French competitors Gabriel Tarde and Henri Bergson. Similar to Bergson, the pragmatists, according to Durkheim, postulate a reverse evolution in which the simplest life form is differentiated and individual and the highest life form is commingling and life-flow. He in contrast sees differentiation of both organic and social life as proof that "creative development" (Bergson) goes in the other direction: from the primitive state of commingling to the current (modern) state of differentiation. The respective central terms - the "stream of experience" (James following Bergson) and the "social fact" (Durkheim) mirror this fundamental difference, further ignited by Durkheim's desire to distance himself from psychology - James' origins - as well as his claim to an objective sociology. ${ }^{6}$ Whereas pure experience as an "experience of actualities" (Lapoujade 2008: 184) is always in the process of becoming, a social fact is also governed by process, but it is the result of differentiation, in particular of the social division of labor. The respective understanding of practice is similar; in Durkheim it is based on a theory of differentiation and is not holistic as in pragmatism. The "organizational plan of experience" (Lapoujade) is for Durkheim also primarily an external factor; it develops within the framework of a collective consciousness which both acts upon the individual and at the same time is created by him. This dual character of experiencing and producing mirrors Durkheim's underlying assumption of homo duplex, whose irreducible social self culminates as "collective representation" in the "social fact", 
in the "association" or even in the "crystallization of social phenomena from social currents" (Durkheim 1981: 173; Durkheim 1954: 433). This genealogical culmination results from an understanding of the social as sui generis, institutionalized within specific social milieus. ${ }^{7}$

Durkheim's sociology oscillates between this processual perspective and an emphasis on the structuring power of social and conventional norms (Durkheim 1953: 24-5; Lukes 1973: 10; Sawyer 2005: 103-4). This oscillation distinguishes both the contradictoriness and the complexity of Durkheim's thought and also makes it thoroughly plausible that he was influenced by both Bergson and James, as this passage from "Sociology and its scientific domain" (1900) shows, a reply to Georg Simmel's essay "Das Gebiet der Soziologie" (the field of sociology):

Without a doubt phenomena concerning structure are somewhat more stable than functional phenomena, but there are only gradual differences between these two orders of facts. Structure itself can only be grasped in becoming and we can only see it as evident by taking into account the process of becoming. Structure is ceaselessly built up and broken down, it is life that has reached a certain degree of consolidation and to separate it from the life from which it has come or the life which determines it is equivalent to taking apart that which is inseparable. (Durkheim 1975: 22)

R. Keith Sawyer correspondingly makes out the following forms of social emergence in Durkheim's oeuvre: "1. The crystallization of social phenomena from social currents. 2. The historical perspective of a social stage from a social milieu, 3 . The emergence of collective representations from the social milieu" (Sawyer 2005: 123). ${ }^{8}$ Collective experience is primarily important for the practice theory dimension of Durkheim's conceptual thought because it reflects the functional interdependence of "impersonal norms of thought" and social practices (Durkheim 1975: 30; Karsenti 2006: 195f.). Durkheim, as a reaction to the accusation that his sociology was similar to Hobbes' or Machiavelli's power theories, holds up the emergent character of collective experience in his "Rules" already linked to the term "association": "But if, contrary to these philosophers, we say that social life is natural, it is not because we find its origin in the nature of the individual; it is because it derives directly from the collective being which is, of itself a nature sui generis; it is because it arises from that special process of elaboration which individual consciousness undergo through their association with each other and whence evolves a new form of existence" (Durkheim 1982: 144). Sawyer trenchantly remarked on the place of consciousness in this context: "Collective representations are of qualitatively different nature than individual representations because they are emergent social facts" (Sawyer 2005: 106). Therefore the collective, external to the individual person, marks the impossibility of reducing the social to the individual subject.

Durkheim's sociologie de l'action thus positions itself as an emergence theory alternative to radical empiricism in which experience and consciousness are historically saturated due to their collectivity - for Durkheim the central characteristic of the modern era. If experience and consciousness are equally central to the constitution of reality for both Durkheim's sociology and James' philosophy of pragmatism, what role does practice play? Here I arrive at the core of Durkheim's criticism of pragmatism, on the basis of which the centrality of practice and its differing functions in sociology and pragmatism becomes clear. 


\subsection{Practice: Action and Knowledge}

16 In his sociophysiological studies, Durkheim uses both the terms "action" and "practice." His professor and supporter in Bordeaux, Alfred Espinas, had already introduced praxéologie as a sociological theory of practice in 1897 (Espinas 1897: 8-9, Filloux 1987: 45-6, Durkheim 1969: 296). James' definition of the term practice on the other hand is greatly influenced by Peirce and signifies an epistemological category the purpose of which is not quite clear, as John Dewey criticized in his 1907 essay "What pragmatism means by practical." For James practice is a distinguishing attribute of an assumed measure of the truth of a statement, although it refers to the hypothetical character of every truth. Truths, as faits accomplis, are not a priori concepts, but are made. Their characteristics are not static, but dynamic and practical (MW 4: 98 ff., Durkheim 1981: 125). This instrumental thought is based on the one hand on an analogy with natural sciences and on the other hand on a concept of experience to which James imparts, as to consciousness, a functional importance for acquiring knowledge. This analogy is clear in the term "experimental thought" that, similar to the French expérimentation subsumes experiment, experience and mental movement. Empiricism is connected with life-worldly and scientific experience, to which a mentalist advantage is given, and now can also be applied methodologically. Dewey remarks on this: "I believe we can say [...] that the development of the idea of experience to which James more than pointed, which he initiated for us, constitutes a revolutionary change in traditional empiricism" (LW 15: 13). Thus "practice" in pragmatism means above all turning away from metaphysical ideas of truth and toward a life-worldly reality (James 1975: 278-9). For this reason, James sees an inseparable connection between practice and knowledge. This connection is created cognitively by experience. Because thought and reality are never completely in concordance, experience has the reality-stabilizing function of bridging this gulf. This fundamental critique of Humes' empiricism, Kant's a priori and the Cartesian cogito is at the same time the foundation for pragmatism's attempt to rehabilitate practice; only when the individual elements of experience (James 1922: 63-4) have become manifest as practice in the Lebenswelt do they create that what Lapoujade termed the "organizational plan" that no longer needs an a priori origin.

Durkheim rejects this theory in its entirety - he sees no affinity between practice and knowledge as they serve completely different functions (Durkheim 1981: 166-7, Thévenot 2006: 190-1). Whereas James and Dewey see "practice" as a variable, a contingent, experimental category that questions existing patterns of behavior and ways of thinking, meant to withstand the danger of a philosophy divorced from life; Durkheim (and later also Bourdieu) emphasizes its repetitive, stabilizing, compulsory and collectivizing aspects which allow individuals only a "relative autonomy" (Durkheim 1953: 23). ${ }^{9}$ Like James, he speaks of an experimental method (Durkheim 1982: 110), but one that differs from all other social sciences - and thus also the philosophy of pragmatism: "The manner in which society is constituted is one thing, how it acts is something completely different. These are two kinds of realities, so different that they cannot be researched using the same procedures and must be separated from one another" (Durkheim 1975: 22). It is this methodological separation that, in a second step necessary to sociology, first enables putting societal practice and general science into the right relationship to one another: "It is true that science can only concern itself with the facts through the mediation of art, but art is only the extension of science" (Durkheim 1982: 87). ${ }^{10}$ According to Anne 
W. Rawls, this argument stems from a theory of practice: "For Durkheim, social practices are not ideal and they do not consist primarily of ideas, representations and beliefs. These are merely secondary phenomena. For Durkheim, society consists first and foremost of enacted practices that give rise to real social forces that participants in the assembled group experience jointly" (Rawls 1996: 434). At the same time, Durkheim's theory is hardly a bottom-up perspective, as Rawls asserts using an interactionist and ethnomethodological approach. Durkheim's definition of practice - though never explicitly stated - is rather situated at the threshold of stability and change that produces the act of association and its crystallization as a practical, emergent phenomenon (Durkheim 1953: 30). This is particularly clear in the understanding of practice in Durkheim's late sociology of religion in which he describes the act of believing as a disposition to act, expressed both in creative (éffervescence, délir) and in everyday acts. This, according to Karsenti, is the important practice theory core of Durkheim's thought: "In other words, the sociological vision never resolves the tension between creation and institutionalization and this is the context in which it poses the question of practice" (Karsenti 2006: 208). According to Durkheim, the relation of thought to reality is therefore "a practical relationship" (Karsenti 2007: 135). The contingency of social practices led him to the fundamental anthropological belief in the duality of consciousness and action, assuming a homo duplex. From Durkheim's viewpoint, consciousness and action are not to be treated on the same ontological plane on which his anti-utilitarian rebuttal of supposed pragmatist utilitarianism is founded - the emergence theory critique of an intentional category of practice, guided by free will. ${ }^{11}$ Durkheim replaces the reciprocal relationship of thought and action based on the underlying assumption of the "reverse evolution" that he imputes to Pragmatism with a psychological theory of differentiation, as Karsenti explains: "[I]t is about understanding imbalance as a pause in movement, which causes thought to emerge and not thought as the trigger of a compensating movement" (Karsenti 2007a: 139). According to Durkheim, consciousness requires the suspension of action in order to unfold at all. Following Karsenti, this is a "process of the idealization of objects through which they are transformed. Such a process is in one sense creative, in the measure to which it is collective" (Karsenti 2007a: 138). This is clear not only in the "Elementary Forms of Religious Life" (Durkheim 1954: 16ff.), but also already in the "Rules" (Durkheim 1982: 39f.) and in Durkheim's writings on individual and collective beliefs, in which he applies emergence theory to the relation between experience, practice and knowledge (Durkheim 1953). Far from negating practice as constituting knowledge, in Durkheim's view it is exactly the process of turning practice into non-practice which is the precondition for knowledge; "a singular practice of thinking, a practice of suspending practice" (Karsenti 2007a: 140).

18 In sum it can be said that Durkheim's epistemology oscillates greatly between social holism on the one hand and a theory of differentiation on the other hand which makes the emergence theory centrality of association plausible. In order to establish social holism (i.e. to grasp it in its complexity) it is important to examine the dualism of action and knowledge and then resolve this dualism though a theory of emergence in the social as sui generis. James no longer needs this dualism. His work is characterized by a complete break with the positivist epistemological position, replaced in radical empiricism by an emergent phenomenology of associated experiences. While Durkheim therefore still needs the dualist opposition of rationalism and empiricism to introduce his sociological method as a way of reconciling them, James positions himself apart from this dualism. 
James' and Durkheim's theories differ in their empiricist radicalism. While Durkheim defends this radicalism by setting his sociological method against a knowledge that is not empirically saturated, James circumvents the latter by means of a scientist cognitive theory of knowledge (MW 12: 205). One could therefore also say that their respective emergent ideas differ in that Durkheim used a conceptual principle to create a connection to life-worldly practices, while James invoked a functionalist principle based on vitalism.

\section{The Epistemological Centrality of Experience and Practice: Dewey and Bourdieu}

John Dewey and Pierre Bourdieu, in their respective fields of philosophy and sociology, were keys in lending a specific epistemological meaning to "practice." In his last lectures at the Collège de France on the epistemological goal of the idea of the social field, Bourdieu defined it as a combination of a comparative method and a dispositional philosophy of action (Bourdieu 2001: 68). The dispositionality of action is an idea Bourdieu began formulating in the 1960s within the framework of his field theory as sens pratique up to his concept of habitus, which stresses the dynamic and processual incorporation of social knowledge. Asked in 1987 the extent to which his ideas coincided with the American tradition of pragmatism, Bourdieu answered:

Indeed, the affinities and convergences are quite striking [...]. [T]he theory of practical sense presents many similarities with theories, such as Dewey's, that grant a central role to the notion of habit, understood as an active and creative relation to the world, and reject all the conceptual dualisms upon which nearly all postCartesian philosophies are based: subject and object, internal and external, material and spiritual, individual and social, and so on. (Bourdieu-Wacquant 1992c: 122)

In this statement, Bourdieu specifies two decisive intersections: the rejection of a dualist, reductionist, purely metaphysical theory of knowledge, also Durkheim's and James' starting point, and the importance of the concept of dispositional practical sense, in the meaning of a performative creative action option also inherent in his idea of habit and especially - as I will examine in further detail below - in Dewey's active experience (experimentation). Dewey describes James' legacy in this area as having in pragmatism laid the foundation to be able to "recognize that experience is an intimate union of emotion and knowledge" (LW 15: 17).

\subsection{Experimental Thought and Practice as a Method of Knowledge}

John Dewey's entire oeuvre is characterized by a deep exploration of experience, practice and knowledge. He concentrates on the connections between naturalistic/natural science instruments of knowledge and a philosophy of action and practice informed by Peirce and James. This is particulary obvious in his pioneer works on experimental psychology and his famous paper on "The Reflex Arc Concept in Psychology" (1896). Similar to James, he accuses modern philosophy of generally ignoring functional thought. He contrasts it with an empirical theory of ideas that he holds up as one of the most important achievements in the history of ideas, able to bring about the true liberation of thought, because the "definition of the nature of ideas in terms of operations to be performed and the test of the validity of the ideas by the consequences of these operations establishes connectivity 
within concrete experience. At the same time, by emancipation of thinking from the necessity of testing its conclusions solely by reference to antecedent existence it makes clear the originative possibilities of thinking" (LW 4: 92). For all pragmatists, and especially for Dewey and George Herbert Mead, Darwins evolutionary theory inspired and justified the importance of functionalism not only within the natural and the life sciences, but also for philosophy and psychology. The groundbreaking changes in the ways knowledge was acquired brought about by modern natural sciences and the consequent necessity of transcending the dualism of theory and practice are ideas Dewey explores in The Quest for Certainty. A Study of the Relation of Knowledge and Action (LW 4). According to Dewey, the dichotomy of practice and theory in which the identity of occidental philosophy was grounded stems from psychological and anthropological uncertainties which made the "quest for cognitive certainty" the most urgent task and can thus be seen as the origin of the development of theory divorced from practice and empiricism. However in the modern era, experimental empiricism and operational thought gained ascendancy in the natural sciences and final leave was taken from the idea of a tangible reality beyond the realm of empirical fact or, as Dewey called it, from a "spectator theory of knowledge. [...] For science in becoming experimental has itself become a mode of directed practical doing" (LW 4: 20). From this, Dewey concludes that

the consequences of substituting search for security by practical means for quest of absolute certainty by cognitive means will then be considered in its bearing upon the problem of our judgments regarding the values which control conduct, especially its social phases. (LW 4:20)

Knowledge is thus for Dewey a specific moment of experience (or "event"), similar to James' pure experience; however neither, as in James, in a vitalist sense nor, as in Durkheim, in the sense of an ordering moment; for Dewey, knowledge is rather the cognitive equivalent to practical research (West 1989b: 188). At the same time, Dewey protested against all forms of naive positivism. Rather he pleads for "a philosophy of experience [which] may be empirical without either being false to actual experience or being compelled to explain away the values dearest to the heart of man" (LW 4: 86). Similar to James, experience and practice close the gap between rationalism and empiricism, however Dewey preferences practice as a inexhaustible source of inspiration for knowledge, particularly in its close tie to more empirical experience:

In reaction against the age-long depreciation of practice in behalf of contemplative knowledge, there is a temptation simply to turn things upside down. But the essence of pragmatic instrumentalism is to conceive of both knowledge and practice as means of making goods - excellencies of all kinds - secure in experienced existence. (LW 4: 30) $)^{12}$

23 As Andreas Hetzel has aptly noted, Dewey thus follows, similar to James, a "strategy of degrounding practice" which rejects the "transcendental philosophical question of metapractical grounds for practice" (Hetzel 2008: 38).

Although he himself remains a philosopher, Dewey connects philosophical epistemological ambitions with a sociological and genealogical perspective. From this Dewey concludes that experience and practice are the categories par excellence for constituting reality for "'practical' means the future responses which an object requires of us or commits us to" (MW 4: 102). Hetzel remarks on Dewey's and James' use of the term practice: "Practice is never completely itself; it acts rather upon something else and defines itself by means of this effectiveness, by means of cause and effect. Theory is not the other of practice, but can be described as a gestalt or figure of this self-difference of 
practice" (Hetzel 2008: 18-9). This idea of practice is reminiscent of Karsenti's analysis of Durkheim's understanding of practice, as opposed to knowledge, as being informed by a theory of differentiation. Practice, because it does not only signify human action for futurity, but is also the expression of the uncertain provisional nature of "active knowledge," is two-sided - both durable and permeable: "The realm of the practical," Dewey wrote, "is the region of change, and change is always contingent; it has in it an element of chance that cannot be eliminated" (LW 4: 16). Dewey's concept of practice questions universalistic and reason-centered definitions of knowledge in the tradition of his predecessor James' radical empiricism, but he hones this concept much more clearly than James in the direction of a social reformist theory of action, a social philosophy of action concerned primarily with showing "how the actual procedures of knowledge, interpreted after the pattern formed by experimental inquiry, cancel the isolation of knowledge from overt action" (Dewey 1930: 49). Dewey thus implicitly takes up the holistic connection of knowledge and action criticized by Durkheim in James' theory, by attempting to empirically connect them in the social Lebenswelt, in order to find answers to social questions. Bourdieu also makes this empirical association.

Pierre Bourdieu's practice theory arose as both an extension of and alternative to Durkheim's sociologie de l'action. While Bourdieu shared Durkheim's insistence on the power of social structures, on objectivity and against all forms of spontaneous sociology as well as his genealogical and relational methodology; he departed from Durkheim in his criticism of a theory-practice dichotomy. If the social subject is inextricably connected to his environment, which in turn helps structure his bodily and historical socialization, then, in Bourdieu's view, a conflict remains that Durkheim ignored: The social division of labor stems not only from the "neutral" ground of differentiation and association, but also on the basis of the epistemological conflict between theory and practice also criticized by Dewey. However Bourdieu's concept of practice is oriented towards Marx's critique of domination, which studies the social division of theory and practice as a fundamental and antagonistic contradiction of capitalist societies. For the anthropological Marx, this critique of domination means locating the constitutive heterogeneity of thought and action so as to create the conditions for overcoming them. In this way Marx also sees thought as another form of social practice, as a non-practice which led to the differentiation of social classes. But how can we grasp this contradiction between practice and non-practice?

Bourdieu's critique follows Marx in the respect that he believes that to comprehend this antagonism, a theoretical construct of the structures which produced it is necessary. Therefore "a theory is needed that looks at the structures from which it comes and which have produced it, without which it cannot see what has caused it. This means that to truly think about social structures [...] it is necessary to think about the preconditions for the separation of practice and theory" (Karsenti 2011: 109). This realization of the necessity of a theoretical construct is at the same time a distrust of its dominance. From this Bourdieu articulated his genetic or constructivist structuralism as opposed to the structuralism of Ferdinand de Saussure and Claude Lévi-Strauss. Similar to Durkheim, an emergence theory concept of structures can be seen in Bourdieu - structures in the process of becoming, dynamic "functional phenomena" which James associated with perceptual consciousness. This emergence theory perspective is exhibited in the interplay that Bourdieu sees between experiences (dispositions), practices, habitus and social structure: "The habitus which, at every moment, structures new experiences in 
accordance with the structures produced by past experiences, which are modified by the new experiences within the limits defined by their power of selection, brings about a unique integration" (Bourdieu 2002: 284). Experiences and practices can, according to Bourdieu, not only transcend the dualism between rationalism and empiricism (as Durkheim noted in his critique of James), but they are also subject to the fact of social inequality. Thus Bourdieu's theory of practice, influenced by Marx, receives a critical function inherent in Durkheim's practical model of differentiation by acting on the political level of "distinction." Experience, practice and knowledge are, for Bourdieu, inseparable from the attempt to transcend the division of theory and practice in the humanities; he thus throws both Durkheim's and Dewey's critique of dualism into relief and adds a political dimension. Unlike Durkheim, who searched for a collective consciousness that first makes social reality possible, Bourdieu concentrates on the reproductive mechanisms of a reality that is not only contingent, but also, due to the dualism of theory and practice, highly conflict-ridden. Bourdieu agrees with Durkheim that knowledge and reality must exhibit a certain degree of homogeneity so that social experience and disposition can assert themselves as rules at all. But in contrast to Durkheim and Dewey, who both created interventionist theories within a social reform approach, Bourdieu understood the break with common sense not only as a methodological necessity, but also as a critique of domination.

The concomitant danger of a structural theoretical determinism is mitigated by the fact that Bourdieu's concept of practice is not only Marxist, but also anthropological; practice originates in the body. In its practice theory dimension, "practice" means the meeting of the body with the world; a body that is both invariant and performative in its materiality. ${ }^{13}$ In this context, Bourdieu refers to the generative and performative principle of practices. The epistemological ambitions of this dynamic idea of practice become clearer in their close connection to the concept of habitus which stems from a specific idea of experiences - a dispositionalist philosophy of practice - an idea that can also be found in Dewey's concept of experience.

\subsection{Experience / Dispositionality / Habitus}

The central importance of experience to Dewey's work is particularly clear in "Experience and Nature." In it, he calls his philosophy not "pragmatism," but "empirical naturalism" or "naturalistic empiricism" (LW 1: 10) and bases it on the preeminent position of human experience (LW 1: 11), a naturalistic, genealogical, fundamental principle already found in James' radical empiricism. How does Dewey define experience differently from James and Durkheim? Which critique of consciousness and epistemological elements is it based on?

For Dewey, experience is both an imminent and an external phenomena, it is the foundation of things: "Experience thus reaches down into nature; it has depth. It also has breadth and to an indefinitely elastic extent. It stretches. That stretch constitutes inference" (LW 1: 13). In contrast to Durkheim, Dewey locates experience in the whole world - here too he links to James' radical empiricist "pure experience" and to the connective relationships between objects, people and experiences. Dewey distinguishes between James' psychological scientific philosophy and speculative philosophy (see MW 12: $203 \mathrm{ff}$;; LW 15: $3 \mathrm{ff}$.), but in contrast to James he emphasizes the sociological and genealogical importance of collective experience and association. He explicitly criticizes the contraposition of individual and society as an artificial opposition which obscures the 
true challenges of the modern era; the "reconstruction of the ways and forms in which men unite in associated activity" in times of rapid social change - a challenge located not between the individual and association, but within them (Dewey 1954: 191). Similar to Durkheim, Dewey concedes that there is a parallel between historical differentiation and association that are, in his opinion, relevant to a theory of practice: "A distinctive way of behaving in conjunction and connection with other distinctive ways of acting, independent of every else, is that toward which we are pointed" (Dewey 1954: 188).

While Bourdieu believed social distinction to be the society forming category par excellence and examined it as such, he locates experience more implicitly within his theories of disposition, practical sense and habitus, which he often used interchangeably and does not consistently distinguish from one another (see Bouveresse 1999: 52). Bourdieu gave up his more explicit term for the importance of experience to behavior and the contingent uncertainty of behavior, hysteresis, more or less completely in the course of his work for the more structurally-oriented concept of habitus. Because of its specific function, particularly relating theory and practice to one another, Bourdieu defines habitus among other things as "history turned into nature" (see Bourdieu 1977: 78) and as a system of disposition. In this sense, the sens pratique, the relational praxeological knowledge expressed via habitus, locates experience/disposition, akin to James' and Dewey's theories, as an anthropological category in opposition to objectivism. Bourdieu defines disposition as the precondition to reflection and action based in experience, both psychologically/mentally as well as structurally and thus, as in Dewey, beyond the artificial dichotomy of individual and society. The term disposition "expresses first the result of a organizing action with a meaning close to words such as structure; it also designates a way of being, a habitual state (especially of the body) and, in particular, a predisposition, tendency, propensity or inclination" (Bourdieu 1977: 214). "Dispositions [are] acquired through experience" (Bourdieu 1990: 9). Elsewhere, Bourdieu speaks of the "homogeneity of conditions, of conditionings, and thus of dispositions" (Bourdieu 1990: 129), or of the "dispositions of agents [...], that is their mental structures" experienced by subjects as the long-term occupation of a position (Bourdieu 1990: 130-1). In this last definition, the function of disposition within his "genetic structuralism" becomes clear: the long-term occupation of a social position, a social inheritance, becomes a disposition founded on Leibniz's mode of relational thinking, which Bourdieu referred to repeatedly (see Bouveresse 1999: 47ff.) and which also influenced James' definition of experience. Between habitus expressed as action and disposition Bourdieu sees an "ontological complicity" (Bourdieu 1990: 12) that anticipates structure; this expresses the function of the sens pratique and is reminiscent of Dewey's definition of practice. The generalizing capabilities of dispositions are hereby not one of a transcendental subject such as found in the idealist tradition, but of an acting and creative agent (Bourdieu 1990: 12).

31 The terminological intersections of disposition, practical sense and practice subsumed by Bourdieu under the concept of habitus also however reveal the fundamental problem of his theory of structure and practice: It is difficult to know when a disposition is more likely to reproduce existing structures and has a stabilizing function and when it is the starting point for a change in what is structurally predetermined. The embodied, performative and transposable nature of habitus ("art of inventing," see Bourdieu 2002: 279) that Bourdieu emphasizes as a defense against the accusation of structural determinism contradicts the duration, persistence and stabilizing tendency ascribed to 
the dispositions it is founded on. Is this an insoluble antagonism, tilted towards structural dominance?

To determine this, in the context of the definition for disposition Bourdieu himself gave, we must clarify the role of the critique of consciousness, which also motivated James' and Durkheim's epistemologies. In contrast to the importance of the social unconscious frequently stressed by Bourdieu, his social theories and in particular the practical sense are often, incidentally similar to pragmatism, understood as close to utilitarian theories (Honneth 1984, Joas \& Knöbl 2004, Dalton 2004) - a reading that rests on the vagueness surrounding the position of consciousness in Bourdieu. Paradoxically, this arises from the creative, performative opening of the idea of habitus in contrast to structural determinism, which Bourdieu often brings into an inauspicious coalition with the strategic orientation of agents, as if agents acted strategically according to the logic of practice most advantageous to them. The equation of a practical sense founded on dispositions with "pre-logical thinking" (Bourdieu 2003: 49) led to further confusion, as this seemed to provide grounds for the conclusion that the sens pratique is located in the realm of the unconscious, a blatant contradiction to his writings on strategic action. It is worth noting that Bourdieu also states that dispositions ignore experiences in thought, but not in practice (Bourdieu 2002: 278), concordant with James' and Dewey's idea of the supremacy of practice over knowledge. From this however does not follow strategic action, but the idea that dispositions which inform the action - the sens pratique - belong in the sphere of the infra-conscious, as Karsenti has shown (Karsenti 2011: 122). For this reason alone, habitus is neither located completely in the conscious sphere or in the unconscious sphere, because it always operates on a specific level of consciousness, namely at an intermediate level. It is both a passive and an active category. The same is true of experience anchored in habitus. From this viewpoint, Bourdieu's conceptualization of experience is the epistemological equivalent to William James' criticism of the concept of consciousness widely held in his times. Although James posited experience in opposition to (metaphysical) consciousness, he did allow for consciousness in a practical sense - recognizing its function for knowledge. However this leads to utilitarianism just as little as Bourdieu's sens pratique does. In this way, Bourdieu's theory of disposition and practical sense, understood as working at an infra-conscious level, just as James' theory of experience, could make the connection necessary to assign consciousness with an equally pre-logical epistemic value, manifested between the conscious and the unconscious, therefore decisively physical and mental.

Missing in Bourdieu however, and ubiquitous in pragmatism, is the search for explanations for structures of emergence and adaptation within social differentiation and the spaces of possibility they create. With the exception of his study on the sociology of art (Bourdieu 1992a) Bourdieu seldom discusses the interaction of specific practices and social structures regarding new or contingent experiences, action options or forms of practice. My thesis is that to do so, we need an emergence theory perspective to hone the practice theory and pragmatist concepts of "knowledge," "experience" and "practice," as I outline in my conclusion. 


\section{Conclusion: Social Emergence Theory as a Point of Convergence?}

Bruno Karsentis' aforementioned thesis - that Durkheim's sociologie de l'action is the sociological counterpart to James' radical empiricism - can be corroborated from the viewpoint of emergence theory. James' radical empiricism poses the question of how experience and knowledge are constituted. His epistemological interest, building on the category of experience, is focused on objects in the process of becoming. According to James, the validity of philosophical scientific truth can only be seen in practice, in its empirical connection to the natural world. Emergence theory takes an ontological holistic approach to this issue; Durkheim takes a more social holistic approach. Durkheim's sociologie de l'action thus positions itself as an emergence theory alternative to radical empiricism in which experience and consciousness are historically saturated due to their collectivity. It is distinguished by a process of differentiation characterized by the interdependence of evolving structures (social morphology) and practices (social physiology). Both vary accordingly between naturalist and constructivist motifs. Although James' epistemological contribution to a grounding "experience" in practice helped bring sociological perspectives into philosophy, ${ }^{14}$ his definition of practice remained epistemological and his understanding of experience was mostly individualist. Durkheim for his part did not see the dualism of theory and practice as an opportunity to connect his emergence theory understanding of the concept of "association" with a critique of consciousness grounded in practice theory. Dewey however does make this connection. Dewey continues James' work by studying the non-causality of practice and its irreducibility to a rational or empirical subject. He expands James' critique of consciousness by describing knowledge as a transactional process based on active, experimental experiences. His criticism of the dissociation of individual and society resulted in a concept of collective associations very close to emergence theory.

The critique of consciousness expressed by James, Durkheim and Dewey by means of the concept of experience is reformulated in the late modern era in Bourdieu's sens pratique. ${ }^{15}$ In James and Dewey, experience - in the sense of mental, internalized infra-conscious knowledge - manifests itself through different series of associations (James 1922: $9 \mathrm{ff}$., LW 1: 266-7), while in Bourdieu's practical sense, which also reproduces the experiences people have on an infra-conscious level, experience contributes to the dynamic organization of reality. The potential of Bourdieu's sociology for emergence theory lies in his method of relating disposition, practices and social structures to one another; they enter empirical interdependencies and produce specific social experiences. However Bourdieu failed to take the necessary step of emergence theory that explains how the interaction of specific practices and social structures lead to the creation of new social fields.

Here, James' and Dewey's emphasis on non-originality, the tendency towards unpredictability as well as the creative, optional and anticipatory character of practice is quite useful, as Bourdieu himself conceded with regard to the sens pratique. In this area, the concept of practice approaches a core concept of emergence theory with respect to its effect on experience and knowledge: Unlike the concept of action, the concept of practice, in Bourdieu's Marxist-influenced terminology as well as in pragmatic philosophy, emphasizes, as Stefan Beck has noted, the "state of tension between stability and 
variation" which is of central importance to an emergence theory perspective. "Practice [...] in Marxist anthropology and in Dewey's pragmatic idea of action is conceptualized in terms of how it acts upon the self and upon the world (Selbst- and Welteinwirkung) whereby processuality and situativity represent two decisive analytic categories" (Beck 1996: 339). Similar to James' notion of pure experience, the open-ended complexity of practice in the context of its development is revealed. The emergent characteristics of social phenomena produced by practice become empirically visible as externally aimed effects, typified by a tendency to be unpredictable. Darwins non-teleogical argument considering the evolution of life translated into the concept of experience by the pragmatists requires it's full legacy here, as Menand stresses: "Relations will be more important than categories, functions, which are variable, will be more important than purposes, which are fixed in advance; transitions will be more important than boundaries; sequences will be more important than hierarchies" (Menand 2002: 124). Here we could dissipate some epistemological tracks of a pragmatism that became later on interactionism and ethnomethodology (Emirbayer \& Maynard 2010).

This associative and collective character of practice and its basic performance arises from the interdependent linkages within the social fabric that goes beyond the idea of the selforganization dynamic of procedures quoted in the definition of emergence promoted by Krohn and Küppers. Moreover, it corresponds with John H. Holland's understanding of emergence as a "product of coupled, context-dependent interactions" (Holland in Beck 2007: 124-5). Sawyer, in his study on social emergence, goes even further: "The science of social emergence is the basic science underlying all of the social sciences because social emergence is foundational to all of them" (Sawyer 2005: 189). At the same time, he protests against creating a new general theoretical paradigm: "The Emergence Paradigm does not propose any definite answers to long-standing sociological questions, but it has significant implications for how sociological theory and methodology should proceed" (Sawyer 2005: 229). Thus emergence theory offers a useful approach to the pragmatic development of practice theory as both concepts see themselves both as theories of knowledge and at the same time as empirical, experimental research methods. In an interview entitled "Fieldwork in Philosophy" in a reference to J. L. Austin, Bourdieu claimed it is necessary to have a pragmatic view of that "culture par excellence, namely philosophy" (Bourdieu 1990: 29). ${ }^{16}$ Perhaps now the time has come to apply this premise to Bourdieu's theory of practice.

In Belgian philosopher Didier Debaise's etymologic definition, the affinity between 'practice' and 'pragma' is obvious: "'Pragma'," he says, "means both, 'experience' and 'praxein' which means 'acting,' 'doing' or even 'performing"' (Debaise 2005). Nevertheless the epistemological dimensions and methodological consequences of the conflation of these categories as "experience," "practice" and "performance" (in the sense of creative action) remain unclear as regards their meaning for cognitive and social freedom and the finiteness of human action. Following Debaise, 'pragma' includes practice, which is merely a specific expression of pragma accompanied by experience. So the difference between pragmatism and practice theory probably lies in the translation of experience into a performative interpretation.

Dealing with experience means for Bourdieu neither reduction, nor pure reproduction, but the limitation of creativity by the habitus as an integration system that gives experiences their intrinsic coherence. Experience in Bourdieu's sense is a process of accumulation and integration. Innovation is immediately absorbed by the integrating 
activity of knowledge production. This process of accumulation and integration is in itself endlessly creative, as Bourdieu acknowledges following Chomsky's model of generative grammar, but the practices it produces are greatly limited by social constraints. In contrast, in pragmatist thought, experience, and in particular "experimentation" describes an activity that is much more instable, unpredictable and ambiguous. As Debaise points out: "Pragmatism presents itself as a technical reflection upon experimentation. This technique takes two forms: the evaluation of the propositions, utterances, and ideas through their effects; the construction and invention of new propositions in charge of accounting for experimentation as a continuous movement of changes and transformations" (Debaise 2005). The practices arising from experimentation are basically emergent, as they appear as qualitatively new forms of symbolic and material complexity empirically embodied in human action.

In this regard, I believe that sociological action theory should today focus more concretely on the empirical foundation of knowledge production in regards to actors specific dispositions, forms of experimentation and emergent practices. By stressing the idea of emergence, human action (or practice) could be understood as a dynamic that highlights and reflects the social persistence of established patterns of assumptions as well as possibilities for innovation and change. But in contrast to established social theories that have already developed around the social impact of emergence, such as those of Niklas Luhman, the conflation of practice theory and pragmatism forces us to recast emergence within qualitative and quantitative observation and methodological reflections on our proper practice as social scientists. Furthermore, both practice theory and pragmatism take a critical analytical stance which concedes a "relative autonomy" (Marx) to social agents as regards their ability to perform their life trajectories. Observing the dynamics of differentiation in contemporary Lebenswelten, we must deal with the concomitance of reproduction and emergence. More precisely, I suspect that a combination of practice theory and pragmatism shall show a dynamic interrelation between the categories sens pratique - disposition - reproduction - experience - emergence. Bourdieu's anthropological category of sens pratique is as suitable for the study of social change as the emergent categories of association and experience formulated by James and Dewey, especially on the question of critical action. The problem of the dichotomy of reflective knowledge and practical knowledge could be resolved by a pragmatist approach without abandoning the methodological equipment of practice theory. In short, the particularities of acting by recasting models of specific dispositions in specific situations (or social fields) could be comprehended, depending on the degree of generalization, by applying both structural analysis and an analysis of emergent processes. Thus, it is possible to articulate the anti-deterministic perspective defended by Bourdieu's sociology and by pragmatism in a manner that stops considering social reproduction and social emergence as mutually exclusive phenomena. By focusing on the idea of emergence in the sense of an empirically based process of knowledge, 'practice' could be understood as a fundamental social dynamic that highlights and reflects the persistence of established social norms and patterns of assumption as well as the possibility of difference, critique, innovation and hence social change. 


\section{BIBLIOGRAPHY}

BASTIDE R., (1958), “Sociologie et psychologie," in Gurvitch G. (ed.), Traité de sociologie. Tome premier , Paris, PUF, 65-82.

BECK S., (1996), Umgang mit Technik. Kulturelle Praxen und kulturwissenschaftliche Forschungskonzepte, Berlin, Akademie Verlag.

BECK S., (2007), “Globalisierte Reproduktionsregimes: Anmerkungen zur Emergenz biopolitischer Handlungsräume," Berliner Blätter. Ethnographische und Ethnologische Beiträge 42, 124-51.

BERGSON H., (1993), “Über den Pragmatismus von William James. Wahrheit und Wirklichkeit," in Bergson H., Denken und schöpferisches Werden, Hamburg, Europäische Verlagsanstalt, 234-45.

BOGUSZ T., (2010), Zur Aktualität von Luc Boltanski. Einleitung in sein Werk, Wiesbaden, Verlag für Sozialwissenschaften.

BOGUSZ T., (2011), “Transdisziplinäre Gewinne einer pragmatischen Soziologie der Arbeit,” in Arbeits- und Industriesoziologische Studien, 2/2011, 116-32.

DEBAISE D. (ed.), (2007), Vie et expérimentation. Peirce, James, Dewey, Paris, Vrin.

DEWEY J., (1916), “What Pragmatism means by 'practical' (On William James)," The Middle Works of J. Dewey, 1899-1924, vol. 4 (MW 4), ed. by J. A. Boydston, Southern Illinois University Press, Carbondale and Edwardsville 1977.

DEWEY J., (1920), “William James (1842-1910),” The Middle Works of J. Dewey, 1899-1924, vol. 12 (MW 12), ed. by J. A. Boydston, Southern Illinois University Press, Carbondale and Edwardsville 1982. DEWEY J., (1925), Experience and Nature, The Later Works of J. Dewey, 1925-53, vol. 1 (LW 1), ed. by J. A. Boydston, Southern Illinois University Press, Carbondale and Edwardsville 1983.

DEWEY J., (1930), The Quest for Certainty. A Study of the Relation of Knowledge and Action, The Later Works of J. Dewey, 1925-53, vol. 4 (LW 4), ed. by J. A. Boydston, Southern Illinois University Press, Carbondale and Edwardsville 1984.

DEWEY J., (1934), Art as Experience, The Later Works of J. Dewey, 1925-53, vol. 10 (LW 10), ed. by J. A. Boydston, Southern Illinois University Press, Carbondale and Edwardsville 1987.

DEWEY J., (1942), “William James as Empiricist,” The Later Works of J. Dewey, 1925-53, vol. 15 (LW 15), ed. by J. A. Boydston, Southern Illinois University Press, Carbondale and Edwardsville 1989.

DEWEY J., (1954), The Public and its Problems, The Later Works of J. Dewey, 1925-53, vol. 2 (LW 2), ed. by J. A. Boydston, Southern Illinois University Press, Carbondale and Edwardsville 1984.

DEWEY J., (1954), The Public and its Problems, Athens, Ohio University Press and Swallow Press.

DIAZ-BOHNE R. \& K. SCHUBERT, (1996), William James zur Einführung, Hamburg, Junius.

DODIER N., (1991), "Agir dans plusieurs mondes," Critique, 529-30 ("Sciences Humaines - sens social"), 427-58.

DODIER N., (2005), “L'espace et le mouvement du sens critique,” Annales 2005/1, 7-31.

DURKHEIM É., (1953), Sociology and Philosophy, London, Cohen \& West. 
DURKHEIM É., (1954), The Elementary Forms of the Religious Life, London, Hollen Street Press.

DURKHEIM É., (1969), Journal sociologique, Paris, Presses Universitaires de France.

DURKHEIM É., (1972), Selected Writings, Edited by Anthony Giddens, Cambridge, Cambridge University Press.

DURKHEIM É., (1975), “La sociologie et son domaine scientifique," in Durkheim É., Textes 1. Éléments d'une théorie sociale, Paris, Éditions de Minuit, 13-36.

DURKHEIM É., (1981), Pragmatisme et sociologie. Cours inédits 1913-14, Paris, Armand Collin.

DURKHEIM É., (1982), The Rules of Sociological Method and Selected Texts on Sociology and its Method, Don Mills, Ontario, Free Press.

DURKHEIM É., (1983), Pragmatism and Sociology, edited and with an introduction by John B. Allcock, Cambridge, Cambridge University Press.

DURKHEIM É., (1984), Die Regeln der soziologischen Methode, Frankfurt am Main, Suhrkamp.

DURKHEIM É., (1985), “Individuelle und kollektive Vorstellungen," in Durkheim É., Soziologie und Philosophie, Frankfurt am Main, Suhrkamp, 45-83.

DURKHEIM É., (1990), Der Selbstmord, Frankfurt am Main, Suhrkamp.

DURKHEIM É., (1993), Schriften zur Soziologie der Erkenntnis, Frankfurt am Main, Suhrkamp.

DURKHEIM É., (1994), Die elementaren Formen des religiösen Lebens, Frankfurt am Main, Suhrkamp.

EMIRBAYER M. \& D. W. MAYNARD, (2010), "Pragmatism and Ethnomethodology," Qualitative Sociology , 2011/34, 221-61.

ESPINAS A., (1897), Les origines de la technologie, Paris, Alcan.

FILLOUX J. C., (1987), “Introduction à Émile Durkheim: La science sociale et l'action” Paris, Presses Universitaires de France, 5-75.

DE FORNEL M. \& C. LEMIEUX (eds.), (2007), Naturalisme versus constructivisme?, Paris, Éditions de l'EHESS.

DE FORNEL M. \& A. OGIEN (eds.), (2011), Bourdieu. Théoricien de la pratique, Paris, Éditions de l'EHESS ("Raisons Pratiques," 21).

Gross N., (2009), “A Pragmatist Theory of Social Mechanisms," American Sociological Review 74, 358-79.

HAMPE M., (2007), Eine kleine Geschichte des Naturgesetzbegriffes, Frankfurt am Main, Suhrkamp. HEINICH N., (1996), Ce que l'art fait à la sociologie, Paris, Minuit.

HETZEL A., KERTSCHER J. \& M. RÖLLI (eds.), (2008), Pragmatismus - Philosophie der Zukunft? Weilerswist, Velbrück.

HONNETH A., (1984), “Die zerrissene Welt der symbolischen Formen. Zum kultursoziologischen Werk Pierre Bourdieus," Kölner Zeitschrift für Soziologie und Sozialpsychologie 36, 147-64.

HÖRNING K. H. \& J. REUTER (eds.), (2004), Doing Culture. Neue Positionen zum Verhältnis von Kultur und sozialer Praxis, Bielefeld, Transcript.

JAMES W., (1922), Essays in Radical Empiricism, New York, Longmans, Green \& Co.

JAMES W., (1978), Pragmatism and The Meaning of Truth, Cambridge, Harvard University Press. 
JAMES W., (1994), Was ist Pragmatismus?, Weinheim, Beltz Athenäum.

JAMES W., (2006), Pragmatismus und radikaler Empirismus, edited by Claus Langbehn, Frankfurt am Main, Suhrkamp.

JOAS H., (1992), Pragmatismus und Gesellschaftstheorie, Frankfurt am Main, Suhrkamp.

JOAS H., (1993), “Durkheim und der Pragmatismus. Bewusstseinspsychologie und die soziale Konstitution der Kategorien," in Durkheim É., Schriften zur Soziologie der Erkenntnis, edited by Hans Joas, Frankfurt am Main, Suhrkamp, 257-88.

JOAS H., (1996), Die Kreativität des Handelns, Frankfurt am Main, Suhrkamp.

JOAS H. \& W. KNÖBL, (2004), "Zwischen Strukturalismus und Theorie der Praxis - die

Kultursoziologie Pierre Bourdieus,” in Joas H. \& Knöbl W. (eds.), Sozialtheorie. Zwanzig einführende Vorlesungen, Frankfurt am Main, Suhrkamp, 518-57.

KARSENTI B. \& L. QUÉRÉ (eds.) (2004), La croyance et l'enquête. Aux sources du pragmatisme, Paris, Éditions de l'EHESS (“Raisons Pratiques," 15).

KARSENTI B., (2006), “La sociologie à l'épreuve du pragmatisme," in Karsenti B., La société en personnes. Études durkheimiennes, Paris, Economica, 183-212.

KARSENTI B., (2007a), “Une alternative au-délà du pragmatisme. La pratique en suspens,” in De Fornel M. \& Lemieux C. (eds.), Naturalisme versus constructivisme, Paris, Éditions de l'EHESS, 133-40.

KARSENTI B., (2011), “De Marx à Bourdieu. Les dilemmes du structuralisme de la pratique," in De Fornel M., Ogien A. (eds.), Bourdieu. Théoricien de la pratique, Paris, Éditions de l'EHESS ("Raisons Pratiques", 21), 103-34.

KROHN W. \& G. KÜPPERS (eds.) (1992), Emergenz: Die Entstehung von Ordnung, Organisation und Bedeutung, Frankfurt am Main, Suhrkamp.

LAHIRE B. (ed.), (2001), Le travail sociologique de Pierre Bourdieu. Dettes et critiques, Paris, La Découverte.

LATOUR B., (2007), "La connaissance est-elle un mode d'existence? Rencontre au muséum de James, Fleck et Whitehead avec des fossiles de chevaux," in Debaise D. (ed.), Vie et expérimentation. Peirce, James, Dewey, Paris, Vrin, 17-43. English version: “A Textbook Case Revisited. Knowledge as Mode of Existence," in Hackett E., Amsterdamska O., Lynch M. \& Wacjman J. (eds.), The Handbook of Science and Technology Studies, Cambridge, Mass, MIT Press, 83-112.

LEPENIES W., (1981), "Normalität und Anormalität. Wechselwirkungen zwischen den Wissenschaften vom Leben und den Sozialwissenschaften," in Lepenies W. (ed.), Geschichte der Soziologie. Studien zur kognitiven, sozialen und historischen Identität einer Disziplin, Frankfurt am Main, Suhrkamp, 227-51.

LUKES S., (1973), Émile Durkheim - His Life and Work. A Historical and Critical Study, Stanford, Stanford University Press.

MARX K., (2005), Ökonomisch-Philosophische Manuskripte, edited by Barbara Zehnpfennig, Hamburg, Felix Meiner Verlag.

MoEBIUS S., (2009), "Marcel Mauss und Pierre Bourdieu," in Rehbein B. \& Fröhlich G. (eds.), Bourdieu-Handbuch, Stuttgart, Metzler, 53-7. 
MÜLLER H. P., (2005), "Handeln und Struktur. Pierre Bourdieus Praxeologie," in Thélène-Colliot C., François E. \& Gebauer G. (eds.), Pierre Bourdieu. Deutsch-Französische Perspektiven, Frankfurt am Main, Suhrkamp, 21-42.

RAWLS A. W., (1996), “Durkheim's Epistemology: The Neglected Argument," The American Journal of Sociology, 102 (2), 430-82.

RECKWITZ A., (2003), “Grundelemente einer Theorie sozialer Praktiken. Eine sozialtheoretische Perspektive," Zeitschrift für Soziologie, 32/4, 282-301.

SAWYER R. K., (2005), Social Emergence. Societies as Complex systems, Cambridge, Cambridge University Press.

SCHATZKI T. R., KNORR-CETINA K. \& E. VON SAVIGNY (eds.), (2001), The Practice Turn in Contemporary Theory, London, Routledge.

SHUSTERMAN R., (1999a), "Introduction: Bourdieu as Philosopher," in Shusterman R. (ed.), Bourdieu. A Critical Reader, Oxford, Blackwell, 1-13.

SHUSterman R., (1999b), “Bourdieu and Anglo-American Philosophy,” in Shusterman R. (ed.), Bourdieu. A Critical Reader, Oxford, Blackwell, 14-28.

THÉVENOT L., (2006), L'action au pluriel. Sociologie des régimes d'engagements, Paris, La Découverte.

THÉVÉNOT L., (2011), "Powers and Oppressions Viewed from the Sociology of Engagements: In Comparison with Bourdieu's and Dewey's Critical Approaches of Practical Activities," Irish Journal of Sociology, 19 (1), special issue "Keys Issues in Contemporary Social Theory," edited by Piet Strydom, 35-67.

WEST C., (1989a), "The Coming-of-Age of American Pragmatism: John Dewey," in West C., The American Evasion of Philosophy. A Genealogy of Pragmatism, Wisconsin/London, University of Wisconsin Press, 69-111.

WEST C., (1989b), "The Decline and Resurgence of American Pragmatism: W. V. Quine and Richard Rorty," in West C., The American Evasion of Philosophy. A Genealogy of Pragmatism, Wisconsin/ London, University of Wisconsin Press, 182-210.

\section{NOTES}

1. For a discussion on a combination of practice theory and pragmatism in order to develop a contemporary theory of social mechanisms, see Gross 2009; for a discussion on Pierre Bourdieu's and John Dewey's approaches to critical activities through the lenses of the French pragmatic sociology of critique, see Thévenot 2001.

2. Krohn and Küpper precede "appearance" with the adverb "sudden," which I have left out. Particularly from a pragmatic/practice theory perspective - and especially in regard to the positions examined here - the processuality of emergent phenomena is always conceivable over a longer period of time (durée). This becomes clearer in the following analysis of the four authors' positions.

3. This is however in dispute in current discourse on pragmatic philosophy and is for example partially contested by Bruno Latour, Didier Debaise, Jean-Christophe Goddard and Pierre Montebello. The "non-anthropological" interpretation of pragmatism, particularly in France, is currently undergoing a reinterpretation with an eye towards the life sciences and technical philosophy prompted by Gabriel Tarde on Henri Bergson, William James, and Alfred North Whitehead on Gilbert Simondon and Gilles Deleuze. 
4. A similar view is found in Joas regarding the agreement of Durkheim and pragmatism on building a "theory of the social constitution of the fundamental category of knowledge" (Joas 1993: 267). However in my opinion this is less true of James who (unlike Durkheim) does not extrapolate from the dualism of practice and knowledge, but radically circumvents the difference between thought and action by preferencing the concept of experience. It is thus presumably experience (Joas 1993: 261) that needs to be questioned as a radical empiricist and sociological term.

5. On the contemporary form of the empirical turn see Joas (1993: 261-2).

6. An excurses on Durkheim's exploration of James' "Principles of Psychology" which runs through his pragmatism lectures would shed more light on this. While some sociologists tended to see psychology primarily as a area of demarcation (particularly true of Pierre Janet's und Gabriel Tardes' psychologie sociale), Durkheim and his student Maurice Halbwachs' psychologie collective repeatedly stresses the importance of psychological knowledge for a sociological analysis (Durkheim 1953: 1-34; Bastide 1958).

7. Here I follow Steven Luke's argument that Durkheim replaced the term "crystallization" with the term "institution" or uses them synonymously.

8. Accordingly, it is possible to interpret Durkheim's statement that sociology is the science of institutions from an emergence theory perspective: Sociology is at the same time a science for studying institutionalizing (Castoriadis) evolving phenomena, "associations," as wells as stabilizing institutions in the meaning of material and moral structures.

9. The term "relative autonomy" already appears in early Marx and is later taken up again by Bourdieu (see Bourdieu 1992: 26; Bogusz 2007: 18ff.).

10. Around 1900, "les arts" was a synonym for practice, Durkheim's supporter Espinas uses the terms interchangeably (Espinas 1897).

11. A criticism that however has no impact, as Joas has shown (see Joas 1993: 263ff.).

12. In Art as Experience (LW 10) Dewey describes the aesthetic character of the "experience of thinking."

13. The interconnection of body and practice suggests epistemological parallels between Bourdieu and Marcel Mauss (Moebius 2009).

14. This also explains Bruno Latour's proximity to James and Dewey, however in his critique of Durkheim he completely ignores Durkheim's emergence theory approach, which leads to a significant distortion of Durkheim's social theory.

15. It remains an open question whether Bourdieu might have been able to build this criticism more solidly if he had stayed with the term hysteresis.

16. Curiously, this passage is missing in the German translation (Bourdieu 1992b).

\section{ABSTRACTS}

The classical philosophy of American pragmatism has experienced a striking renaissance within the social sciences during the last decade especially in France and Germany. My essay takes this development as a starting point to propose a historical and epistemological combination of pragmatism and sociological practice theory from an anthropological viewpoint. In the long run this combination is not only supposed to overcome their pretended incommensurateness in social theory, but to consolidate their methodological convergences, which, while actually 
reclaimed in international social and cultural anthropology, still wait to be applied in a more systematic relation. Hence, the essay examines their respective approaches concerning knowledge , action and the importance of experience starting with William James and Émile Durkheim (1). In a second step, the concepts of experience and practice in the works of John Dewey and Pierre Bourdieu will be compared one to another (2). The essay finishes by outlining a possible combination based on emergence theory that still has to be developped (3).

\section{AUTHOR}

\section{TANJA BOGUSZ}

Centre Marc Bloch Berlin, Humboldt University - Berlin bogusz[at]cmb.hu-berlin.de 